\title{
Pengaruh Metode Eksperimen Sains Terhadap Perkembangan Kognitif Anak Usia 5-6 Tahun
}

\author{
Rahyana Hasibuan ${ }^{1 凶}{ }^{\circledR}$, Dadan Suryana ${ }^{1}$ \\ Pendidikan Anak Usia Dini, Universitas Negeri Padang, Indonesia(1) \\ DOI: $\underline{10.31004 / \text { obsesi.v6i3.1735 }}$
}

\begin{abstract}
Abstrak
Perkembangan kognitif sangat penting agar anak tersebut mampu melakukan eksplorasi terhadap dunia disekitarnya. Permasalahan kognitif anak usia dini di TK Al Hikmah pada penelitian ini adalah terdapat anak dengan kemampuan kognitif yang rendah, anak terlihat kurang semangat dan juga kurang antusias dalam mengikuti pembelajaran. Tujuan penelitian ini adalah untuk mengetahui dan menganalisis apakah ada pengaruh metode eksperimen terhadap perkembangan kognitif anak, metode yang dicobakan / treatment adalah metode eksperimen sains yaitu gelembung sabun warna dan botol berbunyi. Jenis penelitian ini adalah kuantitatif eksperimen dengan menggunakan clasical eperimental design, dengan acuan cluster sampel dengan jenis total sampling, sampel pada penelitian ini berjumlah dua puluh dua anak yang masing-masing terdiri dari kelas kontrol dan kelas eksperimen. Teknik pengumpulan data pada penelitian ini adalah berupa tes perbuatan, dari hasil penelitian terlihat bahwa kelas eksperimen lebih tinggi dibandingkan kelas kontrol maka dapat disimpulkan bahwa terdapat pengaruh metode eksperimen terhadap perkembangan kognitif anak.
\end{abstract}

Kata Kunci: metode eksperimen sains; anak usia dini; perkembangan kognitif.

\begin{abstract}
The cognitive development is very important so that the child is able to explore the world around him. The cognitive problems of young children at Al Hikmah Kindergarten in this study are that there are include low cognitive abilities, less enthusiasm and also less enthusiasm in participate in learning. The purpose of this study was to determine and analyze whether there is an effect of the experimental method on children's cognitive development, the method being tried / treatment is a science experimental method, namely colored soap bubbles and bottles. This type of research is a quantitative experiment using a classical experimental design, with a reference cluster sample with a total sampling type, the sample in this study amounted to twenty-two children, each consisting of a control class and an experimental class. The data collection technique in this study is in the form of an action test, from the results of the study it can be seen that the experimental class is higher than the control class, so it can be concluded that there is an effect of the experimental method on children's cognitive development.
\end{abstract}

Keywords: science experiment method; young children; development cognitive.

Copyright (c) 2021 Rahyana Hasibuan, Dadan Suryana

$\triangle$ Corresponding author :

Email Address : rahyanahasibuan@gmail.com (Padang, Sumatera barat, Indonesia)

Received 9 May 2021, Accepted 20 August 2021, Published 27 August 2021 


\section{PENDAHULUAN}

Anak usia dini adalah kelompok anak yang berada dalam proses pertumbuhan dan perkembangan yang bersifat unik (Martinis, 2012). Pendidikan anak usia dini adalah pendidikan yang sangat mendasar atau merupakan suatu upaya pembinaan yang ditujukan bagi anak sejak lahir sampai usia anak enam tahun yaitu anak yang berada pada rentan usia 0-6 tahun (Rakimahwati, 2018). Anak usia dini memiliki pola pertumbuhan dan perkembangan yang khusus sesuai dengan tingkat pertumbuhan dan perkembangan. Bahkan usia dini dikatakan sebagai usia emas, yaitu usia yang sangat berharga dibandingkan usiausia selanjutnya sampai anak dewasa. Pembelajaran anak usia dini ini, dilihat dari beberapa prinsip diantaranya adalah anak harus memiliki kesiapan secara umur, kemampuan fisik, kematangan mental dan emosional, dikemas dalam bentuk bermain dan permainan, dan banyak melibatkan anak (Mayar, 2013). Taman Kanak-kanak adalah satuan pendidikan yang sangat penting dalam mengembangkan potensi yang ada pada anak dan dapat mengembangkan berbagai aspek perkembangan anak (Nurhafizah, 2015).

Berbagai pendapat mengenai pengertian anak usia dini dapat dijadikan acuan untuk memberi batasan yang sangat jelas mengenai hakikat anak usia dini. The National Association for Eduation of Young Children (NAEYC) menyatakan bahwa yang dimaksud dengan masa kanak-kanak dini atau early childhood adalah anak yang sejak lahir sampai dengan anak berusia delapan tahun. Pengertian diatas sejalan dengan teori psikologi perkembangan dan berdasarkan riset neurologi tentang pertumbuhan pada otak anak (Suryana, 2012). Usia dini meliputi anak yang berusia 0-8 tahun. Oleh karena itu, apabila dilihat dari jenjang pendidikan yang berlaku di Indonesia maka yang termasuk dalam kelompok anak usia dini tersebut adalah anak baru lahir, masa bayi, kelompok bermain, taman kanak-kanak, dan di lanjutkan pada sekolah dasar pada kelas rendah (Rahelly, 2018). Pembelajaran anak usia dini harus dapat memberikan kesempatan kepada anak untuk mendapatkan proses pembelajaran yang ilmiah (SURYANA, 2017).

Pandangan para ahli pendidikan mengenai anak usia dini juga cenderung berubah dari waktu ke waktu dan berbeda dengan satu sama lain sesuai dengan landasan teori yang telah digunakan. Sebagian pendapat ada yang memandang bahwa anak sebagai makhluk yang sudah terbentuk oleh bawaannya, dan ada pula yang menganggap anak sebagai miniatur dari orang dewasa, serta ada juga yang memandang bahwa anak sebagai individu yang berbeda total dari orang dewasa. Misalnya, Pestalozi, seorang yaitu seorang ahli pendidikan Swiss, memandang bahwa anak terlahir dengan bawaan yang baik atau natural. la memandang bahwa eksistensi manusia ada dalam proses evolusi alam (Prasetyo, 2016). Perkembangan manusia terjadi dalam desain alam dan terbentuk dari kekuatan-kekuatan luar. Menurutnya, hukum-hukum fungsional menyebabkan akan terjadinya suatu proses pertumbuhan dan perkembangan yang sangat berkesinambungan, serta juga bertahap. Anak juga merupakan masa depan generasi yang memiliki potensi untuk berkembang secara optimal, maka pendidikan yang diberikan harus sesuai dengan tahapan perkembangannya (Nurhafizah, 2017).

Bidang pengembangan anak dalam pendidikan anak usia dini ada enam, keenam bidang ini harus dikembangkan untuk mengasah kemampuan anak sebagai modal dasar bagi kehidupan mereka nanti yaitu diantaranya: nilai agama dan moral, fisik motorik, sosial emosional, kognitif, bahasa dan seni. Salah satu bidang yang perlu di tonjolkan kepada anak usia dini adalah kognitif, karena pada bidang pengembangan kognitif meliputi kemampuan berfikir kritis dan penyelesaian masalah, Anak usia dini juga memiliki motif yang kuat ke arah pembentukan sendiri dalam jiwanya (self contruction), dengan dorongan ini seorang anak usia dini secara spontan berupaya mengembangkan dalam membentuk dirinya melalui pemahaman terhadap lingkungannya anak (Yaswinda, 2018). Anak dapat menguasai sejumlah pengetahuan, keterampilan dasar dan kreativitas sesuai dengan kebutuhan (Mayar, 2019). 
Untuk mengembangkan pola perkembangan psikis anak tersebut, dilakukan sejak kecil melalui pengalaman-pengalaman interaksi pendidikan anak. Kondisi yang diperlukan untuk perkembangan ini, antara lain yaitu adanya interaksi yang terpadu antara anak dengan lingkungannya, dan adanya kebebasan bagi anak (Pebriana, 2017). Kemampuan kognitif anak berkaitan dengan perkembangan bahasa yaitu seperti: memahami kata, mengeluarkan apa yang dia pikirkan, kemampuan logis, seperti memahami sebab akibat suatu kejadian. Piaget menyatakan bahwa perkembangan kognitif adalah proses interaksi yang berlangsung antara anak dan juga pandangan perseptual terhadap sebuah benda atau kejadian di suatu lingkungan anak. Menurut teori Jean Piaget anak-anak usia dini membangun pengetahuan mereka melalui eksplorasi aktif pada anak terhadap lingkungannya (Suryana, 2013). Perkembangan kognitif anak adalah salah satu aspek yang dapat mempengaruhi pada pertumbuhan dan perkembangan anak usia dini tersebut.

Perkembangan kognitif anak usia dini adalah suatu proses dengan berpikir berupa kemampuan untuk menghubungkan, menilai dan juga mempertimbangkan sesuatu (Khadijah, 2016). Dapat juga dimaknai sebagai kemampuan anak untuk memecahkan suatu masalah atau menciptakan karya yang dihargai pada kebudayaan. Setiap anak berbeda dan tentunya setiap perkembangan kognitif pada setiap usia anak juga memiliki permasalahan yang berbeda (Anida \& Eliza, 2020). Adapun permasalahan kognitif anak usia dini di TK Al Hikmah Kecamatan Sosa Kabupaten Padang Lawas Provinsi Sumatera Utara pada penelitian ini antara lain, bahwa terdapat anak dengan kemampuan kognitif yang rendah, dalam hal ini peneliti telah melakukan pengamatan awal bahwa masih banyak terlihat anak-anak yang belum bisa merespon dan juga menjawab pertanyaan yang diberikan guru pada saat proses pembelajaran dilaksanakan contohnya pada saat pembelajaran mewarnai gambar, kemudian anak terlihat kurang semangat dan juga kurang antusias dalam mengikuti pembelajaran. Dengan adanya permasalahan tersebut maka sangat dibutuhkan metode yang tentunya akan dapat membantu perkembangan kognitif anak usia dini. Menurut Nurhafizah (2018) metode yang diciptakan secara mandiri oleh guru dapat membantu dan lebih mudah menyampaikan sebuah pembelajaran kepada anak seperti dengan permainan, kita dapat memberi kesempatan pada anak untuk mempelajari dan mempraktekkan cara baru dalam berfikir, merasakan dan bertindak.

Dalam mengembangkan kognitif anak usia dini, metode eksperimen dapat mendorong proses pertumbuhan dan perkembangan pada anak (Khaeriyah, 2018). Pembelajaran metode eksperimen sains dalam mengembangkan kognitif anak usia dini dalam pengembangan visual yaitu gelembung sabun warna, pada percobaan ini berhubungan pada kemampuan penglihatan, pengamatan dan perhatian. Kemudian perkembangan auditorik botol berbunyi, pada percobaan ini lebih ditekankan pada kemampuan anak dalam mendengar yang melalui proses menerima kumpulan suara benda. Pada metode eksperimen sains tersebut, guru dapat memberikan cara pada pengalaman terhadap anak usia dini dalam proses pembelajaran dengan melakukan berbagai percobaan terhadap sesuatu media yang digunakan dengan cara melihat dan mengamati akibatnya (Suryameng \& Marselina, 2019). Seperti penelitian yang dilakukan oleh (Dewi et al., 2016) dengan hasil penelitian yaitu penerapan metode eksperimen dapat meningkatkan kemampuan kognitif anak dengan dilakukannya tindakan siklus I dan siklus II dengan skor rata-rata kemampuan kognitif sebesar 0,72 . Perbedaan penelitian ini dengan penelitian sebelumnya adalah pada penelitian ini anak lebih banyak bermain sambil belajar karena dengan permainan kita dapat memberi kesempatan pada anak untuk mempelajari dan memperaktekkan cara baru dalam berfikir, merasakan, dan juga bertindak dan memberikan kebebasan kepada anak saat bermain gelembung sabun warna dan botol berbunyi.

Berdasarkan permasalahan latar belakang di atas, dapat dirumuskan masalah yaitu: apakah ada pengaruh metode eksperimen terhadap kognitif anak di TK Al Hikmah Kecamatan Sosa Kabupaten Padang Lawas Provinsi Sumatera Utara. Adapun tujuan pada penelitian ini adalah untuk mengetahui pengaruh metode eksperimen terhadap kognitif anak 
usia dini di TK Al Hikmah Kecamatan Sosa Kabupaten Padang Lawas Provinsi Sumatera Utara.

\section{METODOLOGI}

Jenis penelitian yang ditetapkan adalah penelitian kuantitatif eksperimen dengan menggunakan clasical eperimental design, dengan acuan cluster sampel dengan jenis total sampling. Metode penelitian kuantitatif adalah penelitian yang memiliki syarat berupa nuansa angka angka dalam teknik pengumpulan data di lapangan (Rangkuti, 2016). Menurut Bungin (2011) penelitian kuantitatif digunakan untuk mengarahkan peneliti menemukan masalah penelitian, menemukan hipotesis, menemukan konsep-konsep, menemukan metodologi dan menemukan alat-alat analisis data. Penelitian ini yang menjadi populasi yaitu seluruh anak usia dini di TK Al Hikmah Kecamatan Sosa Kabupaten Padang Lawas Provinsi Sumatera Utara dengan jumlah 44 anak. Dilakukan dengan teknik total sampling karena dalam penentian sampel pada penelitian ini semua anggota populasi digunakan sebagai sampel. Teknik total sampling pada populasi dalam penelitian ini yaitu seluruh anak usia dini di TK Al Hikmah yang berjumlah 44 anak, dengan kelas kontrol berjumlah 22 anak, kelas eksperimen berjumlah 22 anak.

Penelitian ini dilakukan dengan perlakuan / treatment metode eksperimen sains. Metode eksperimen merupakan cara yang memberikan pengalaman kepada anak yang dalam proses pembelajaran dengan melakukan berbagai percobaan terhadap sesuatu media yang digunakan dengan cara melihat dan mengamati akibatnya (Anwar, 2014). Pelaksanaan metode eksperimen ini cukup memerlukan peralatan dan sarana yang memadai sebelum pembelajaran dimulai, pada eksperimen kali ini akan di bahas tentang melukis dengan gelembung sabun warna, dan semua peralatan akan disiapkan untuk kelancaran percobaan ini karena tanpa peralatan yang memadai metode ini tidak akan bisa dilaksanakan. Proses jalannya penelitian yaitu sebagai berikut: langkah-langkah metode eksperimen gelembung sabun warna dengan menggambar dengan gelembung sabun warna, dimana pada kegiatan ini anak akan disuruh memilih warna apa saja yang mau di gambar sesuai dengan warna kesukaan anak. Tujuannya adalah mengenalkan kepada anak pencampuran warna dan anak berkreasi membuat gelembung di atas kertas. Kemampuan kognitif anak dalam penelitian ini adalah kemampuan anak untuk dapat berkreasi dan menyebutkan warna dasar, dapat menceritakan kembali proses menggambar dengan gelembung sabun. Anak melakukan kegiatan mencampur warna di mulai dari menjelaskan nama-nama alat dan bahan yang akan digunakan untuk membuat lukisan gelembung sabun warna.

Adapun alat dan bahan yang akan digunakan antara lain: pewarna makanan, air, sedotan, sabun cuci, kertas HVS, aqua gelas. Adapun langkah-langkah metode eksperimen yaitu sebagai berikut: Guru memberikan penjelasan kepada anak tentang kegiatan yang akan di eksperimenkan, menjelaskan kepada anak nama-nama alat dan bahan yang akan dieksperimenkan, meminta anak memilih sesuai warna kesukaan yang akan dibuat gelembung warna dan akan digambar di kertas HVS, Setelah sudah selesai dijelaskan kepada anak, kemudian anak diminta untuk mengikuti sesuai dengan tahapan yang akan dieksperimenkan, pertama, aqua gelas diisi air, pewarna makanan dan sabun cuci sedikit saja, yang penting ada gelembungnya, kemudian diaduk, kemudian sedotan yang sudah dipersiapkan dibentuk yaitu ujung pipet tersebut dibuat melingkar, kemudian di celupkan ke aqua gelas yang sudah diisi, kemudian ditiup, setelah itu, kertas HVS diletakkan dilantai dengan tujuan, ketika gelembungnya sudah ditiup akan jatuh ke kertas HVS dan kemudian akan membentuk pola gambar yang berwarna-warna.

Langkah - langkah metode eksperimen botol berbunyi. Pada percobaan botol berbunyi yaitu anak akan membedakan botol mana yang nyaring bunyinya diantaranya botol kosong, diisi air dan diisi air banyak. Kemampuan kognitif anak dalam penelitian ini adalah anak mampu mendengar bunyi-bunyi dengan baik dan mampu menjelaskan bunyi botol dengan suara kecil, sedang dan nyaring. Adapun alat dan bahan yang akan digunakan antara lain: 
botol, sumpit/kayu dan air. Adapun langkah-langkah metode eksperimen yaitu sebagai berikut: Guru memberikan penjelasan kepada anak tentang kegiatan yang akan di eksperimenkan, guru memasukkan air sedikit dan banyak ke dalam botol, dan ada juga botol yang dikosongkan, kemudian guru meminta anak mencoba memukul botol dengan sumpit, kemudian bertanya kepada anak bagaimana bunyi botol yang di isi air sedikit, banyak dan yang kosong, anak menjawab sesuai dengan botol yang dipukul, botol yang diisi air banyak bunyinya kecil, botol yang diisi sedikit bunyinya sedang sementara botol yang kosong bunyinya nyaring.

Teknik pengumpulan data pada penelitian ini adalah dengan menggunakan tes perbuatan. Adapun tes yang digunakan pada penelitian ini yaitu dengan memberikan tes awal (pretest) dan juga tes akhir (posttest). Peneliti berharap metode eksperimen dapat memiliki nilai manfaat sebagai pengisi waktu luang dan kegiatan pada pembelajaran sehingga anak dapat berekspresi, karena anak-anak dapat menghasilkan waktu dengan berjam-jam untuk bereksperimen seperti membuat gelembung dari sabun warna dan botol berbunyi.

\section{HASIL DAN PEMBAHASAN}

Penelitian ini dilakukan dengan perlakuan metode eksperimen sains, kemampuan kognitif anak dalam kegiatan menggambar dengan gelembung sabun membuat anak dapat berkreasi dan menyebutkan warna dasar, dapat menceritakan kembali proses menggambar dengan gelembung sabun. Anak melakukan kegiatan mencampur warna di mulai dari menjelaskan nama-nama alat dan bahan yang akan digunakan untuk membuat lukisan gelembung sabun warna, dan kemampuan kognitif anak dalam kegiatan botol berbunyi adalah anak mampu mendengar bunyi-bunyi dengan baik dan mampu menjelaskan bunyi botol dengan suara kecil, sedang dan nyaring.

Penulis mengumpulkan data dengan menggunakan teknik tes perbuatan, data yang dideskripsikan pada penelitian ini terdiri dari hasil perhitungan data pretest dan postest di olah dan diperoleh dari hasil analisis uji paired samples test melalui aplikasi IBM SPSS Statistik 22:

Tabel 1. Analisis Data Hasil Uji Normalitas Postest Kelas Kontrol dan Kelas Eksperimen

Test of Normality

\begin{tabular}{lrrrrrr}
\hline & \multicolumn{3}{c}{ Kolmogorov-Smirnov $^{\mathrm{a}}$} & \multicolumn{3}{c}{ Shapiro-Wilk } \\
& Statistic & Df & \multicolumn{1}{c}{ Sig. } & Statistic & \multicolumn{1}{c}{ Df } & \multicolumn{1}{c}{ Sig. } \\
\hline Postest_Kelas_Kontrol & .155 & 22 & .186 & .928 & 22 & .112 \\
Postest_Kelas_Eksperimen & .162 & 22 & .136 & .943 & 22 & .226 \\
\hline
\end{tabular}

Pada tabel 1 menjelaskan tentang hasil uji normalitas, uji normalitas tersebut dilakukan untuk melihat apakah data tersebut berdistribusi normal. Pada kolom Shapiro Wilk didapatkan pada posttest kelas kontrol yaitu dengan $\mathrm{P}=0,112$. Sedangkan pada kelas eksperimen didapat dengan $\mathrm{P}=0,226$. Signifikansi yang sudah diperoleh dibandingkan dengan alpha yaitu sebesar 0,05 karena tingkat kepercayaan yang telah dipilih peneliti adalah sebesar 95\%. Dari taraf P yang telah dipilih, maka kaidah penetapan kenormalannya yaitu apabila $\mathrm{P}$ yang diperoleh $>0,05$ maka data berdistribusi normal, sedangkan $\mathrm{P}$ yang diperoleh $<0,05$ maka data berdistribusi tidak normal. Karena 0,112 >0,05 maka data yang diperoleh dari pretest kelas kontrol berdistribusi normal begitu juga dengan kelas eksperimen datanya bedistribusi normal karena 0,226 $<0,05$ maka datanya berdistribusi normal.

Pada tabel 2 menggunakan Uji homogenitas varians yang digunakan untuk mengetahui apakah varians pada kelas kontrol dengan kelas eksperimen adalah sama (homogen) ataukah berbeda. Setiap kaidah penetapan kehomogenan data sama dengan kaidah penetapan pada kenormalan suatu data yaitu apabila $\mathrm{P}$ based on mean yang berarti berdasarkan rata rata yang diperoleh $>0,05$ maka data homogen sedangkan $P$ yang diperoleh pada based on mean $<0,05$ maka data tidak homogen. Karena nilai $\mathrm{P}=0,849$, dan 0,849 $>0,05$ 
maka data yang diperoleh dari posttest kelas kontrol dan kelas eksperimen merupakan data homogen.

Tabel 2. Data Hasil Uji Homogenitas Postest Kelas Kontrol dan Kelas Eksperimen

\begin{tabular}{|ll|r|r|r|r|}
\hline \multicolumn{6}{|c|}{ Test of Homogeneity of Variance } \\
\hline & \multicolumn{1}{c|}{$\begin{array}{l}\text { Levene } \\
\text { Statistic }\end{array}$} & \multicolumn{1}{c|}{ df1 } & \multicolumn{1}{c|}{ df2 } & \multicolumn{1}{c|}{ Sig. } \\
\hline Postest & Based on Mean & .037 & 1 & 42 & .849 \\
& Based on Median & .053 & 1 & 42 & .820 \\
& Based on Median and & .053 & 1 & 40.743 & .820 \\
& with adjusted df & .035 & 1 & 42 & .853 \\
\hline
\end{tabular}

Tabel 3. Hasil Perhitungan Pretest Metode Eksperimen dalam Mengembangkan Kognitif Anak Usia Dini

Descriptive Statistic

\begin{tabular}{lcccccc}
\hline & N & Minimum & Maximum & Sum & Mean & Std. Deviation \\
\hline $\begin{array}{l}\text { Pretest_Kelas_ } \\
\text { Kontrol }\end{array}$ & 22 & 35 & 75 & 1125 & 51.14 & 9.249 \\
$\begin{array}{l}\text { Pretest_Kelas_ } \\
\begin{array}{l}\text { Eksperimen } \\
\text { Valid N }\end{array}\end{array}$ & 22 & 35 & 80 & 1180 & 53.64 & 13.018 \\
(listwise) & 22 & & & & & \\
\hline
\end{tabular}

Pada tabel 3 terdapat jumlah anak pada kelas kontrol yaitu sebanyak 22 anak, dan di kelas eksperimen juga memiliki jumlah sebanyak 22 anak. Nilai tertinggi pada kelas kontrol sebanyak 75 dan kelas eksperimen sebanyak 80. Nilai terendah pada kelas kontrol yaitu 35 dan pada kelas eksperimen 35. Jumlah nilai pada kelas kontrol sebanyak 1125 dan pada kelas eksperimen sebanyak 1180. Nilai rata-rata pada kelas kontrol yaitu 51,14 pada kelas eksperimen 53,64. Standar deviasi pada kelas kontrol adalah sebanyak 9,249 dan pada kelas eksperimen yaitu 13,018. Dari hasil data yang didapat bahwa terdapat perbedaan mean kelas kontrol dan kelas eksperimen sehingga terdapat pengaruh metode eksperimen terhadap perkembangan kognitif anak.

Tabel 4. Hasil Perhitungan Postest Metode Eksperimen dalam Mengembangkan Kognitif Anak Usia Dini

Descriptive Statistics

\begin{tabular}{lcccccc}
\hline & N & Minimum & Maximum & Sum & Mean & Std. Deviation \\
\hline Postest_Kelas_Kontrol & 22 & 45 & 80 & 1335 & 60.68 & 10.834 \\
Postest_Kelas_Eksperimen & 22 & 50 & 95 & 1645 & 74.77 & 11.900 \\
Valid N (listwise) & 22 & & & & & \\
\hline
\end{tabular}

Pada tabel 4 terdapat jumlah anak pada kelas kontrol yaitu sebanyak 22 anak, dan di kelas eksperimen juga memiliki jumlah sebanyak 22 anak. Nilai tertinggi pada kelas kontrol sebanyak 80 dan kelas eksperimen sebanyak 95. Nilai terendah pada kelas kontrol yaitu 45 dan pada kelas eksperimen 50. Jumlah nilai pada kelas kontrol sebanyak 1335 dan pada kelas eksperimen sebanyak 1645. Nilai rata-rata pada kelas kontrol yaitu 60,68 pada kelas eksperimen 74,77. Standar deviasi pada kelas kontrol adalah sebanyak 10,834 dan pada kelas eksperimen yaitu 11,900. Dari hasil data yang didapat bahwa terdapat perbedaan mean kelas kontrol dan kelas eksperimen sehingga terdapat pengaruh metode eksperimen terhadap perkembangan kognitif anak. 
Tabel 5. Hasil Analisis Uji Hipotesis Kelas Kontrol dan Kelas Eksperimen

\begin{tabular}{|c|c|c|c|}
\hline \multicolumn{4}{|c|}{ Paired Samples Test } \\
\hline & & & Pair 1 \\
\hline & & & $\begin{array}{c}\text { Uji_Hipotesis } \\
\text {-Penelitian }\end{array}$ \\
\hline \multirow[t]{5}{*}{ Paired Differences } & Mean & & 66.227 \\
\hline & Std. Deviation & & 13.051 \\
\hline & Std. Error Mean & & 1.967 \\
\hline & $95 \%$ Confidence Interval & Lower & 62.260 \\
\hline & of the Difference & Upper & 70.195 \\
\hline $\mathrm{t}$ & & & 33.661 \\
\hline df & & & 43 \\
\hline Sig. (2-tailed) & & & .000 \\
\hline
\end{tabular}

Pada tabel 5, uji hipotesis dilakukan untuk mengetahui apakah hipotesis alternatif yang sudah ditetapkan diterima atau tidak. Pada pengujian hipotesis yaitu jika $\mathrm{P}=0,05$ maka terjadi penolakan $H_{a}$. (Hipotesis alternatif yang sudah ditetapkan peneliti sebelumnya) dan penerimaan $H_{0}$ sedangkan jika $\mathrm{P}=0,05$ maka terjadi penolakan $H_{0}$ dan penerimaan $H_{a}$. $H_{a}$ berarti terdapat pengaruh metode eksperimen dalam mengembangkan kognitif anak usis dini di TK Al Hikmah Kecamatan Sosa Kabupaten Padang Lawas Provinsi Sumatera Utara, Dari pengujian uji sampel berpasangan didapatkan nilai $\mathrm{P}=0,000$ dan oleh karenanya $0,000<$ 0,05, atau dengan melihat nilai $\mathrm{T}_{\text {hitung }}>\mathrm{T}_{\text {tabel }}$ adalah 33,661 > 2,021 maka dapat disimpulkan bahwa terdapat pengaruh metode eksperimen dalam mengembangkan kognitif anak usia dini.

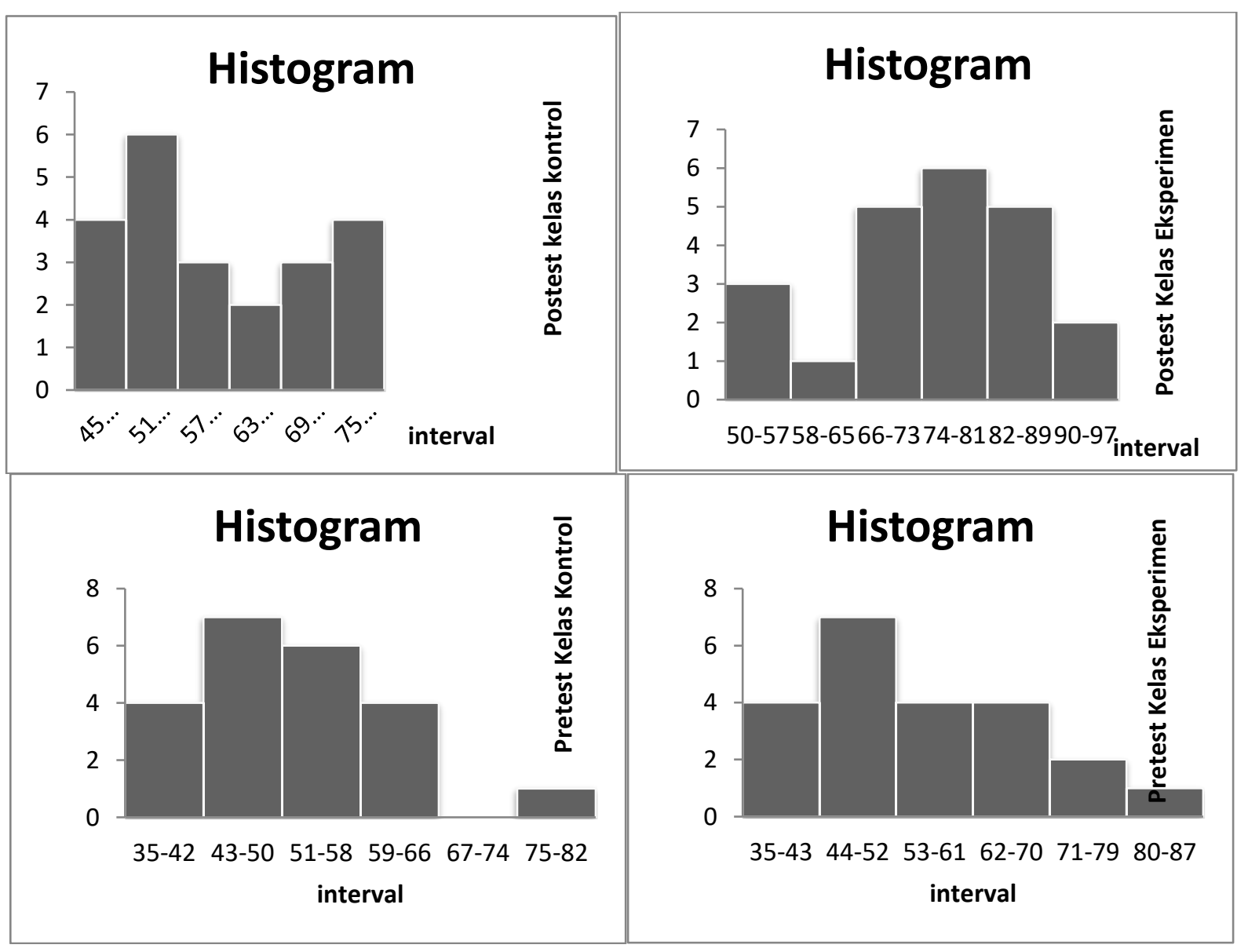

Gambar 1. Histogram Hasil Pretest dan Posttest Kelas Kontrol dan Eksperimen 


\section{Pembahasan}

Anak usia dini adalah sosok yang sangat membutuhkan stimulasi secara maksimal dalam proses pertumbuhan dan perkembangan karena pertumbuhan dan perkembangan pada anak usia dini terjadi ecara pesat. Periode keemasan tersebut hanya berlangsung satu kali sepanjang rentang kehidupan manusia, sehingga anak usia dini disebut berada pada usia kritis. Anak usia dini belajar dengan caranya sendiri yaitu anak memiliki kebebasan untuk bergerak, berperilaku, dan menyatakan pendapatnya tanpa terbebani dengan tekanan psikologis (Mayar, 2019). pengembangan anak dalam pendidikan anak usia dini ada enam, keenam bidang ini harus dikembangkan untuk mengasah kemampuan anak sebagai modal dasar bagi kehidupan mereka nanti yaitu diantaranya: nilai agama dan moral, fisik motorik, sosial emosional, kognitif, bahasa dan seni (Wulandari \& Purwanta, 2020). Salah satu bidang yang perlu di tonjolkan kepada anak usia dini adalah kognitif, karena pada bidang pengembangan kognitif meliputi kemampuan berfikir kritis dan penyelesaian masalah, Anak usia dini juga memiliki motif yang kuat ke arah pembentukan sendiri dalam jiwanya (self contruction), dengan dorongan ini seorang anak usia dini secara spontan berupaya mengembangkan dalam membentuk dirinya melalui pemahaman terhadap lingkungan anak.

Perkembangan kognitif anak melibatkan proses belajar yang progresif misalnya perhatian, logika berfikir dan ingatan. Perkembangan kognitif merupakan tingkat kemampuan anak dalam berfikir. Perkembangan kognitif sangat penting, seperti teori piaget yang merupakan teori yang berfokus pada kemampuan kognitif anak dari kecil sampai memasuki usia remaja, teori piaget tersebut dicetus oleh seorang ahli yang bernama jean piaget (Kasumayanti \& Elina, 2018). Pada penelitiannya mengenai perkembangan kognitif, teori piaget tersebut membagi tahapan pada perkembangan kognitif ini terbagi menjadi empat bagian yaitu sensory motorik (0-2 tahun), pra operasional (2-7 tahun), operasional konkret (711 tahun), operasional formal (11-15 tahun). Salah satu metode yang dapat diterapkan dalam pembelajaran anak usia dini yaitu metode eksperimen. Metode eksperimen merupakan cara yang dapat digunakan untuk menyajikan pembelajaran dimana anak melakukan percobaan dengan mengalami dan membuktikan sendiri sesuatu yang sudah dipelajarinya.

Penelitian yang dilakukan oleh (Khairani, 2018) ditemukan permasalahan dalam penelitiannya seperti kegiatan pembelajaran masih berpusat pada guru sehingga kurang memberikan kesempatan kepada anak untuk melakukan eksperimen dan pemebelajaran yang diberikan oleh guru kurang bervariasi. Berdasarkan hasil penelitian tersebut menyatakan bahwa terdapat perbedaan yang signifikan antara metode eksperimen terhadap kemampuan sains anak. Perbedaan penelitian tersebut dengan penelitian ini adalah bahwa penelitian tersebut guru hanya mengenalkan metode eksperimen tanpa anak bereksplorasi atau anak tidak langsung terjun untuk melakukan eksperimen tersebut, sedangkan pada penelitian ini yaitu pada metode eksperimen sains ini anak diberikan kebebasan untuk bereksperimen, guru dapat memberikan cara pada pengalaman anak usia dini dalam proses pembelajaran dengan melakukan berbagai percobaan terhadap sesuatu media yang digunakan dengan cara melihat dan mengamati akibatnya (Suryameng \& Marselina, 2019). Seperti penelitian yang dilakukan oleh (Dewi et al., 2016) dengan hasil penelitian yaitu penerapan metode eksperimen dapat meningkatkan kemampuan kognitif anak dengan dilakukannya tindakan siklus I dan siklus II dengan skor rata-rata kemampuan kognitif sebesar 0,72. Perbedaan penelitian ini dengan penelitian sebelumnya adalah pada penelitian ini anak lebih banyak bermain sambil belajar karena dengan permainan kita dapat memberi kesempatan pada anak untuk mempelajari dan memperaktekkan cara baru dalam berfikir, merasakan, dan juga bertindak dan memberikan kebebasan kepada anak saat bermain gelembung sabun warna dan botol berbunyi.

Penelitian yang sudah dilakukan dengan mengambil sampel menggunakan teknik total sampling pada populasi dalam penelitian ini yaitu seluruh anak usia dini di TK Al Hikmah yang berjumlah 44 anak, dengan kelas kontrol berjumlah 22 anak, kelas eksperimen berjumlah 22 anak dengan rentang usia 5-6 tahun. Dilakukan sebanyak enam kali pertemuan terdiri dari satu kali pretest, empat kali treatment, satu kali posttest. Pada pretest dan posttest kelas 
eksperimen dilakukan oleh peneliti sementara pada kelas kontrol di lakukan oleh guru yang diamati oleh peneliti.

Hasil pretest terdapat nilai tertinggi pada kelas kontrol sebanyak 75 dan kelas eksperimen sebanyak 80. Nilai terendah pada kelas kontrol yaitu 35 dan pada kelas eksperimen 35. Jumlah nilai pada kelas kontrol sebanyak 1125 dan pada kelas eksperimen sebanyak 1180. Nilai rata-rata pada kelas kontrol yaitu 51,14 pada kelas eksperimen 53,64. Standar deviasi pada kelas kontrol adalah sebanyak 9,249 dan pada kelas eksperimen yaitu 13,018. Dari hasil data yang didapat bahwa terdapat perbedaan mean kelas kontrol dan kelas eksperimen sehingga terdapat pengaruh metode eksperimen terhadap perkembangan kognitif anak. Selanjutnya hasil posttest nilai tertinggi pada kelas kontrol sebanyak 80 dan kelas eksperimen sebanyak 95. Nilai terendah pada kelas kontrol yaitu 45 dan pada kelas eksperimen 50. Jumlah nilai pada kelas kontrol sebanyak 1335 dan pada kelas eksperimen sebanyak 1645. Nilai rata-rata pada kelas kontrol yaitu 60,68 pada kelas eksperimen 74,77. Standar deviasi pada kelas kontrol adalah sebanyak 10,834 dan pada kelas eksperimen yaitu 11, 900. Dari hasil data yang didapat bahwa terdapat perbedaan mean kelas kontrol dan kelas eksperimen sehingga terdapat pengaruh metode eksperimen terhadap perkembangan kognitif anak.

Dilanjutkan pada hasil perhitungan uji hipotesis dilakukan untuk mengetahui apakah hipotesis alternatif yang sudah ditetapkan diterima atau tidak. Pada pengujian hipotesis yaitu jika $\mathrm{P}=0,05$ maka terjadi penolakan $H_{a}$. (Hipotesis alternatif yang sudah ditetapkan peneliti sebelumnya) dan penerimaan $H_{0}$ sedangkan jika $\mathrm{P}=0,05$ maka terjadi penolakan $H_{0}$ dan penerimaan $H_{a} . H_{a}$ berarti terdapat pengaruh metode eksperimen dalam mengembangkan kognitif anak usis dini di TK Al Hikmah Kecamatan Sosa Kabupaten Padang Lawas Provinsi Sumatera Utara, Dari pengujian uji sampel berpasangan didapatkan nilai $\mathrm{P}=0,000$ dan oleh karenanya $0,000<0,05$, atau dengan melihat nilai $\mathrm{T}_{\text {hitung }}>\mathrm{T}_{\text {tabel }}$ adalah 33,661 $>2,021$ maka dapat disimpulkan bahwa terdapat pengaruh metode eksperimen dalam mengembangkan kognitif anak usia dini.

Berdasarkan pembahasan di atas, maka dapat disimpulkan bahwa metode eksperimen sains dapat mempengaruhi perkembangan kognitif anak usia 5-6 tahun. Dilihat pada saat peneliti melakukan eksperimen atau percobaan gelembung sabun warna dan botol berbunyi di kelas eksperimen lebih baik daripada di kelas kontrol, jadi dapat disimpilkan bahwa metode eksperimen sains berpengaruh terhadap perkembangan kognitif anak usia 5-6 tahun di TK AL Hikmah kecamatan sosa kabupaten padang lawas.

\section{SIMPULAN}

Kemampuan kognitif anak dalam kegiatan menggambar dengan gelembung sabun membuat anak dapat berkreasi dan menyebutkan warna dasar, dapat menceritakan kembali proses menggambar dengan gelembung sabun. Anak melakukan kegiatan mencampur warna di mulai dari menjelaskan nama-nama alat dan bahan yang akan digunakan untuk membuat lukisan gelembung sabun warna, dan kemampuan kognitif anak dalam kegiatan botol berbunyi adalah anak mampu mendengar bunyi-bunyi dengan baik dan mampu menjelaskan bunyi botol dengan suara kecil, sedang dan nyaring. Perkembangan kognitif anak di TK Al Hikmah berkembang dengan baik, terdapat pengaruh metode eksperimen terhadap perkembangan kognitif anak.

\section{UCAPAN TERIMA KASIH}

Ketua Peneliti dan anggota mengucapkan terimakasih kepada Tim dan Yayasan Taman Kanak-kanak Al Hikmah Kecamatan Sosa Kabupaten Padang Lawas Provinsi Sumatera Utara atas kerjasamanya dan seluruh pihak yang sudah berkontribusi dan juga berpartisipasi pada penelitian yang dilakukan. 


\section{DAFTAR PUSTAKA}

Anida, A., \& Eliza, D. (2020). Pengembangan Model Pembelajaran Saintifik Berbasis Kearifan Lokal untuk Perkembangan Kognitif Anak Usia 5-6 Tahun. Jurnal Obsesi : Jurnal Pendidikan Anak Usia Dini, 5(2), 1556-1565. https://doi.org/10.31004/obsesi.v5i2.898

Anwar, C. (2014). Hakikat Manusia dalam Pendidikan sebuah Tinjauan Filosofis. Yogyakarta : Suka Press.

Burhan, B. (2017). Metode Penelitian Kuantitatif Edisi Kedua (Komunikasi, ekonomi, Dan Kebijakan Publik, Serta Ilmu Sosial Lainnya), Jakarta : Kencana.

Dewi, I., Gading, I. K., \& ... (2016). Penerapan Metode Eksperimen dalam Pembelajaran Sains untuk Meningkatkan Kemampuan Kognitif Anak Usia Dini. ... Anak Usia Dini Undiksha, https:// ejournal.undiksha.ac.id/index.php/JJPAUD/article/view/8834

$4(3)$.

Kasumayanti, E., \& Elina, Y. (2018). Perkembangan Kognitif Anak Usia 5-6 Tahun di Tinjau dari Tingkat Pendidikan Ibu Di Paud Kasih Ibu Kecamatan Rumbai. PAUD Lectura: Jurnal Pendidikan Anak Usia Dini, 1(2), 186-197. https:// doi.org/10.31849/paudlectura.v1i2.1179

Khadijah. (2016). Pengembangan Kognitif Anak Usia Dini. Perdana Publishing.

Khaeriyah, E., Saripudin, A., \& Kartiyawati, R. (2018). Penerapan Metode Eksperimen dalam Pembelajaran Sains untuk Meningkatkan Kemampuan Kognitif Anak Usia Dini. AWLADY: Jurnal Pendidikan Anak, 4(2), 102. https://doi.org/10.24235/awlady.v4i2.3155

Khairani, M. (2018). Pengaruh Metode Eksperimen Terhadap Kemampuan Sains Anak Usia 56 Tahun Di TK Salsa Percut Sei Tuan. Journal Usia Dini, 4(2), 31-38. https:// doi.org/10.21107/pgpaudtrunojoyo.v5i2.5441

Martinis, Y. (2012). Panduan PAUD (Pendidikan Anak Usia Dini ). Jakarta: Gaung Persada Press Group.

Mayar, F. (2013). Perkembangan sosial anak usia dini sebagai bibit untuk masa depan bangsa. Al-Ta Lim Journal, 20(3), 459-464. https:// doi.org/10.15548/jt.v20i3.43

Mayar, F., Husin, S. H., \& Sari, K. (2019). Peningkatan Kemampuan Kreatifitas Anak Melalui Kegiatan Menggambar Bebas Setiap Hari di Taman Kanak-kanak Darussalam Gadut. Jurnal Pendidikan Tambusai, 3(6), 1365-1373.

Mayar, F., Roza, D., \& Delfia, E. (2019). Urgensi Profesionalisme Guru PAUD dalam Mengembangan Kreativitas Anak Usia Dini. Jurnal Pendidikan Tambusai, 3(5), 1113 1119. https://www.jptam.org/index.php/iptam/article/view/328

Nurhafizah. (2018). Pelatihan Pembuatan Media Pembelajaran Anak Usia Dini Menggunakan Bahan Sisa. Jurnal Pendidikan : Early Childhood Nurhafizah Pendidikan Merupakan Proses, 2(2), 1-10. https://doi.org/10.35568/earlychildhood.v2i2b.288

Nurhafizah, N., \& Kosnin, A. M. (2015). Implementasi Permainan Tradisional Indonesia di Taman Kanak-Kanak Kota Padang. Pedagogi: Jurnal Ilmiah Ilmu Pendidikan, 15(1), 8593. http:// ejournal.unp.ac.id/index.php/pedagogi/article/view/5249/4137

Nurhafizah, N., \& Moh.Kosnin, A. (2017). The Development of Children's Social-Emotional Competences: A Case Study in UNP's Labschool-Kindergarten, Padang Indonesia. 58, 369-374. https:// doi.org/10.2991/icece-16.2017.64

Pebriana, P. H. (2017). Analisis Penggunaan Gadget terhadap Kemampuan Interaksi Sosial. Jurnal Obsesi: Jurnal Pendidikan Anak Usia Dini, 1(1), 1. https://doi.org/10.31004/obsesi.v1i1.26

Prasetyo, S. (2016). Implikasi Ajaran Pestalozzi Dalam Pembelajaran Sains di MI/SD Penyelenggara Inklusi. Jurnal Pendidikan Dasar Islam, 8(1), 90-111.

Rahelly, Y. (2018). Implementasi Kurikulum 2013 Pendidikan Anak Usia Dini (PAUD) di Sumatera Selatan. JPUD - Jurnal Pendidikan Usia Dini, 12(2), 381-390. https://doi.org/10.21009/JPUD.122.21 
DOI: $10.31004 /$ obsesi.v6i3.1735

Rakimahwati, R., Lestari, N. A., \& Hartati, S. (2018). Pengaruh Kirigami Terhadap Kemampuan Motorik Halus Anak di Taman Kanak-Kanak. Jurnal Obsesi : Jurnal Pendidikan Anak Usia Dini, 2(1), 98. https://doi.org/10.31004/obsesi.v2i1.13

Rangkuti, A. N. (2016). Metode Penelitian Pendidikan. Bandung: Citapustaka Media.

Suryameng, S., \& Marselina, T. Y. (2019). Metode Eksperimen Dalam Pembelajaran Sains Untuk Meningkatkan Kemampuan Kognitif Anak Usia Dini Di Tk Santa Yohana Antida 2 .... DUNIA ANAK: Jurnal ..., 1(1). https://doi.org/10.31932/jpaud.v1i2.388

Suryana, D. (2012). Ilmu Pendidikan Anak Usia Dini (Teori dan Praktek Pembelajaran). Jurusan Pendidikan Guru Pendidikan Anak Usia Dini Fakultas Ilmu PendidikanUniversitas Negeri Padang.

Suryana, D. (2013). Pendidikan Anak Usia Dini (Teori dan Praktik Pembelajaran). Padang: UNP Press.

Suryana, D. (2017). Pembelajaran Tematik Terpadu Berbasis Pendekatan Saintifik Di Taman Kanak-Kanak. JPUD - Jurnal Pendidikan Usia Dini, 11(1), 67-82. https://doi.org/10.21009/JPUD.111.05

Wulandari, H., \& Purwanta, E. (2020). Pencapaian Perkembangan Anak Usia Dini di Taman Kanak-kanak selama Pembelajaran Daring di Masa Pandemi Covid-19. Jurnal Obsesi : Jurnal Pendidikan Anak Usia Dini, 5(1), 452. https:/ / doi.org/10.31004/obsesi.v5i1.626

Yaswinda, Y., Yulsyofriend, Y., \& Mayar, F. (2018). Pengembangan Bahan Pembelajaran Sains Berbasis Multisensori Ekologi Bagi Guru Paud Kecamatan Tilatang Kamang Kabupaten Agam. Yaa Bunayya: Jurnal Pendidikan Anak Usia Dini, 2(2), 13-22. 